\title{
Sorptive flotation of Eu(III)-loaded clays from aqueous solutions
}

\author{
Abdelhakim Kandil ${ }^{1}$, Amir Ezzat ${ }^{2}$, Mamdoh R. Mahmoud ${ }^{3}$, Mohamed A. Soliman ${ }^{4}$, \\ Ebtissam. A. Saad ${ }^{2}$ \\ ${ }^{1}$ Chemistry Department, Faculty of Science, Helwan University, Cairo, Egypt \\ ${ }^{2}$ Chemistry Department, Faculty of Science, Ain Shams University, Cairo, Egypt. \\ ${ }^{3}$ Nuclear Chemistry Department, Hot Laboratories Center, Atomic Energy Authority, P.O. Box 13759, \\ Inshas, Cairo, Egypt. \\ ${ }^{4}$ Egypt Second Research Reactor, Atomic Energy Authority, P.O. Box 13759, Inshas, Cairo, Egypt.
}

\section{Abstract}

The present paper investigates the removal of $\mathrm{Eu}(\mathrm{III})$ from aqueous solutions by a sorptive flotation process. Eu(III) removal is achieved by adsorption onto bentonite and kaolinite followed by floatation using sodium dodecyl sulfate(SDS) and cetyltrimethylammonium bromide(CTAB) collectors. The effect of adsorption parameters $(\mathrm{pH}$, contact time, clay weight, and initial $\mathrm{Eu}(\mathrm{III})$ concentration) as well as flotation parameters (collector and frother concentrations, and bubbling time) on the removal efficiency of Eu(III) were studied. Results show that Eu(III) ions are removed efficiently ( $\sim 95 \%)$ at $\mathrm{pH}=4$ after $1 \mathrm{~h}$ shaking with clays and $15 \mathrm{~min}$ floatation

Keywords: sorptive flotation, radioactive waste, europium, bentonite, kaolinite

\section{Introduction}

Radioisotopes of europium (ex: ${ }^{152} \mathrm{Eu}$ and ${ }^{154} \mathrm{Eu}$ ) are of the most hazardous contaminants present in radioactive wastewater due to their relatively high energy (hard $\gamma$ emitters) and long half-lives. [For ${ }^{152} \mathrm{Eu}\left(\mathrm{T}_{1 / 2}=13.2 \mathrm{y}\right)$ three $\mathrm{\gamma}$-lines 122,344 and $1408 \mathrm{keV}$, For

${ }^{154} \mathrm{Eu}\left(\mathrm{T}_{1 / 2}=8.5 \mathrm{y}\right)$ two $\mathrm{y}$-lines 123 and $\left.1274 \mathrm{keV}\right]$. Besides, $\mathrm{Eu}(\mathrm{III})$ is usually taken as homologue for trivalent actinides because the ionic radii of Eu(III) is almost the same for all the trivalent lanthanides and actinides, which result in a similar physicochemical behavior of Eu(III) with the trivalent lanthanides and actinides.

Removal of radioactive contaminants is essential for environmental pollution control. Several techniques are available for the removal of hazardous ions from aqueous solutions including chemical precipitation, solvent extraction, micellar ultrafiltration, organic and inorganic ion exchangers and adsorption. Among these, the adsorption technique is considered very important because of its cost effective treatment, easy operation, narrow space for building the plant, no chemical reagents needed and no sludge produced.

Corresponding author: Abdelhakim Kandil ${ }^{1}$ e-mail: abdelhakimkandil@yahoo.com 
Natural clays are considered as a low-cost adsorbent for this purpose (Hennig et al., 2002). Various types of clays as low-cost adsorbents for heavy metal removal have been reported (Katsumata et al., 2003). Bentonite and kaolinite are well-defined naturally occurring minerals with high an adsorption capacity. The potential adsorption sites for metal ions on bentonite and kaolinite include silanol $\equiv \mathrm{SiOH}$ and aluminol $\equiv \mathrm{AIOH}$, hydroxyl groups on the mineral edges and the permanently charged sites $₫ \equiv X^{-}$, on the basal surface. The application of these clays for environmental pollution control in terms of metal removal from industrial effluents, leachates and contaminated ground water has received much attention (Mathews et al., 1999; Cooper et al., 2002). Hazardous metals-loaded clays are very difficult to be separated from the solution and unsuitable for column use. Researchers' attention has been focused in finding simple, less expensive and effective process for the separation of metalloaded clays from solutions. This approach could be realized by the use of adsorptive flotation technique. This technique has shown much promise for the removal of many inorganic pollutants and radionuclides, from aqueous solutions and wastes (Cayllahua and Torem 2011; Rubio et al., 2002; Chang et al., 2009; Zamboulis et al., 2004; Santander et al., 2011).

For sorptive flotation, the ionic species to be removed (europium in the present case) is first adsorbed onto a suitable material, clay in the present case. A surfactant (the collector) is then added to the suspension and well mixed whereby it coats the surfaces of the sorbent particulates rendering them more hydrophobic. A gentle stream of fine gas bubbles is then allowed to pass through the suspension to levitate the particulates, in the form of a scum, atop the surface (Zamboulis et al., 2004)

\section{Materials and Methods}

\section{Experimental}

\section{Reagents}

All reagents used in this work were of analytical reagent grade chemicals and were used without further purification and all solutions were prepared with distilled water. Europium was supplied as europium (III) nitrate pentahydrate from Sigma Aldrich Company. The radioactive europium was prepared by irradiating europium nitrate in the Egypt Second Research Reactor, at Inshas site. Bentonite and kaolinite are exploited from Kasr El Sagha, Fayoum, Egypt and are commercially available.

Hydrochloric acid and ammonium hydroxide solutions, at various concentrations, prepared from the reagent grade chemicals were used to adjust the $\mathrm{pH}$.

The collectors sodium dodecyl sulfate (SDS) and cetyltrimethylammonium bromide (CTAB) were obtained from Aldrich Chemical Company. Absolute ethanol was used as a frothing agent. 


\section{Sorption Experiments}

The effect of $\mathrm{pH}$ on sorption of $\mathrm{Eu}(\mathrm{III})$ onto bentonite and kaolinite clay was carried out by contacting $10 \mathrm{~mL}$ of $1 \times 10^{-4} \mathrm{M} \mathrm{Eu}$ (III) solution spiked with ${ }^{152+154} \mathrm{Eu}$ with $0.1 \mathrm{~g}$ of the sorbent in $25 \mathrm{~mL}$ glass bottles. The $\mathrm{pH}$ was carefully adjusted to the desired value by adding small amounts of dilute $\mathrm{HCl}$ or $\mathrm{NH}_{4} \mathrm{OH}$ solution using a pH meter (HANNA type, $\mathrm{HI}$ 8519). The contact time was kept at $3 \mathrm{~h}$ which is more than sufficient to reach equilibrium. At the end of the contact time, the samples were centrifuged for $10 \mathrm{~min}$ at a speed of 5,000 rpm and the remaining ${ }^{152+154} \mathrm{Eu}$ in the supernatant was determined.

Kinetic studies onto $0.1 \mathrm{~g}$ clay were carried out by batch adsorption method at temperature of $30 \pm 1{ }^{\circ} \mathrm{C}$ in a temperature-controlled water bath shaker (Karl Kolb type, D6072 Dreieich, Germany) using $25 \mathrm{~mL}$ Pyrex glass bottles containing $10 \mathrm{~mL}$ of $1 \times 10^{-4} \mathrm{M} \mathrm{Eu}$ (III) solutions spiked with traces of ${ }^{152+154} \mathrm{Eu}$. The $\mathrm{pH}$ of the solutions was adjusted to about 4 .

For all the experiments, after agitation, the solutions were centrifuged for $10 \mathrm{~min}$ at speed of 5,000 rpm and the remaining ${ }^{152+154} \mathrm{Eu}$ in the supernatant was determined radiometrically. Generally, each experiment was performed three times at least under identical conditions and the standard deviation never exceeded $4 \%$.

For ${ }^{152+154}$ Eu determination, the activities of solution samples before and after sorption were measured radiometrically using a well type $\mathrm{Nal}(\mathrm{T} 1)$ scintillation detector connected to Ortec EG\&G single channel analyzer. Removal percentage of E(III) was calculated as follows:

$$
\text { Removal \% }=\left(A_{i}-A_{e}\right) / A_{i} \times 100
$$

Where $A_{i}$ and $A_{e}$ are the initial and equilibrium radioactivities of ${ }^{152+154} \mathrm{Eu}$ in the solution, respectively.

\section{Flotation system and general procedure of sorption flotation}

The flotation procedure and system used were previously described in detail (Shakir et al., 1987; Shakir et al., 1993). The flotation cell itself was made of G4 sintered glass disc of $3.6 \mathrm{~cm}$ diameter fused to a Pyrex glass column about $40 \mathrm{~cm}$ in height, drawn at the bottom into the form of a funnel. A tap was sealed to the flotation column at $1 \mathrm{~cm}$ above the sintered disc to enable sample withdrawing for analysis and $\mathrm{pH}$ measurement.

The flotation procedure, generally adopted, consisted of transferring $100 \mathrm{ml}$ of europium-clay suspension, of the desired $\mathrm{pH}$, to the flotation cell. Pure nitrogen gas was bubbled through the suspension at a rate of $25 \mathrm{~cm}^{3} / \mathrm{min}$, unless otherwise stated. The solution of the collector and ethanol was injected in one injection while vigorously stirring the suspension in the flotation cell. 


\section{Results and Discussion}

\section{Sorption studies}

\section{Effect of pH}

The solution $\mathrm{pH}$ is an important factor affecting both the sorbate and sorbent properties. The effect of $\mathrm{pH}$ on the sorption of $1 \times 10^{-4} \mathrm{M} \mathrm{Eu}(\mathrm{III})$ onto bentonite and kaolinite was carried out in the $\mathrm{pH}$ range of about $1-10$. Fixed sorbent weight $(0.1 \mathrm{~g})$, constant solution volume $(10 \mathrm{~mL})$ and constant shaking time $(1 \mathrm{~h})$ were taken into consideration in studying the effect of $\mathrm{pH}$. The results obtained are depicted in Fig. 1 together with the precipitation curve of $\mathrm{Eu}(\mathrm{III})$. As shown from this figure, sorption of $\mathrm{Eu}(\mathrm{III})$ onto both bentonite and kaolinite is strongly dependent on the solution $\mathrm{pH}$. By increasing the solution $\mathrm{pH}$, the sorption percentage $\mathrm{Eu}(\mathrm{III})$ increases to reach the maximum value at $\mathrm{pH} 4$. At neutral and alkaline media, the sorption of Eu(III) ion was nearly constant due to starting of precipitation of $\mathrm{Eu}(\mathrm{III})$ as shown in the precipitation curve for europium. The reason for low sorption in acidic solution $(\mathrm{pH}<4)$ is the competition between the excess of $\mathrm{H}^{+}$ions in the medium and positively charged cationic species of Eu(III) present in the solution (Parks, 1964). Also, higher acid concentrations suppress hydrolysis of the metal ions. In addition, as $\mathrm{pH}$ increases there is a decrease of positive surface charge, which results in lower columbic repulsion of the sorbing metal ions (Villaescusa et al., 2000), It is observed that as the $\mathrm{pH}$ increases, the sorption percentage increases which can be explained on the basis of increase in the negative surface charge of clay. The variation of surface charge density with increasing $\mathrm{pH}$ can be a result of the ionization of surface silanol groups. With increasing adsorption density hydrogen ions pass from the surface to solution, and thus change the $\mathrm{pH}$ of the bulk solution (Low et al., 1995).

The negative surface charge of clay increases with increasing the $\mathrm{pH}$ of the medium as mentioned before. In the present study, it was supposed that there is an electrostatic attraction between the positively charged ions and the negative charged of clay.

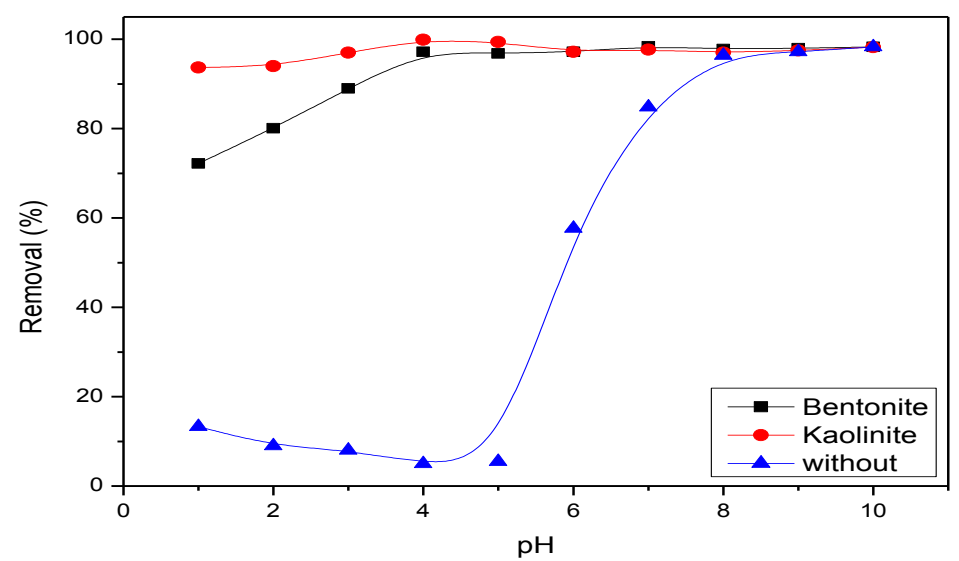

Fig. 1: Effect of the solution $\mathrm{pH}$ on the removal efficiency of Eu(III) by bentonite and kaolinite. $\left(C_{M}=10^{-4} \mathrm{M}, t_{e q} 60 \mathrm{~min}\right.$. , clay $0.1 \mathrm{~g}$, temperature $\left.298 \pm 1 \mathrm{~K}\right)$ 


\section{Kinetic studies}

The effect of contact time $(1-180 \mathrm{~min})$ on sorption of $1 \times 10^{-4} \mathrm{M} \mathrm{Eu}(\mathrm{III})$ onto the employed clays was investigated at $\mathrm{pH}=4$ and temperature of $30 \pm 1^{\circ} \mathrm{C}$ using affixed sorbent weight of $0.1 \mathrm{~g}$. The obtained results are shown in Fig. 2. From this figure it can be seen that the applied clays have high affinity for Eu(III) where almost complete removals are obtained for Eu(III) at $1 \mathrm{~min}$. To ensure equilibration, a contact time of $60 \mathrm{~min}$ was applied throughout the experimental work.

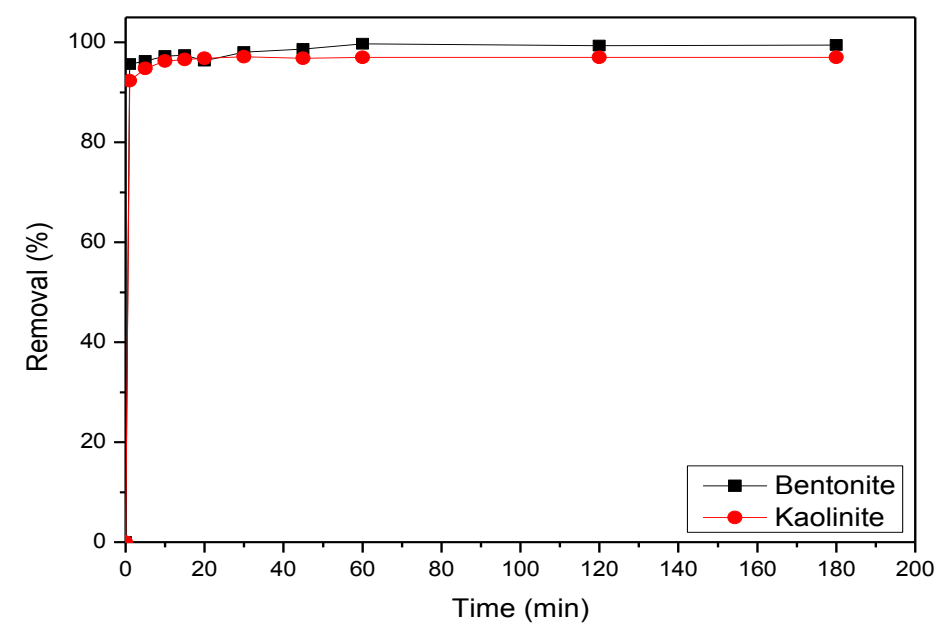

Fig. 2: Effect of contact time on adsorption of Eu(III) using bentonite and kaolinite $\left(\mathrm{C}_{\mathrm{M}}=10^{-}\right.$

${ }^{4} \mathrm{M}, \mathrm{pH}=4$, clay $0.1 \mathrm{~g}$, temperature $298 \pm 1 \mathrm{~K}$ ).

\section{Effect of sorbent weight}

The effect of clay weight on the sorption efficiency of $1 \times 10^{-4} \mathrm{M} \mathrm{Eu}(\mathrm{III})$ is represented in Fig. 3. From this figure, it can be clearly observed that the removal efficiency of Eu(III) is slightly affected by the weight of bentonite. Removal percentages of 93.5 and $>99 \%$ are obtained at bentonite dosages of 0.01 and $0.04 \mathrm{~g}$, respectively. On the other hand, the sorption process of $\mathrm{Eu}(\mathrm{III})$ is significantly dependent on the kaolinite weight. Removal percentage of $20 \%$ is obtained at $0.01 \mathrm{~g}$ compared to $97.5 \%$ at $0.1 \mathrm{~g}$. At clay dosages higher than $0.04 \mathrm{~g}$ (for bentonite) and $0.1 \mathrm{~g}$ (for kaolinite), the removal percentage of Eu(III) remained unchanged. The data of this figure also indicate that Eu(III) ions are effectively removed by bentonite than kaolinite. At $0.01 \mathrm{~g}$ sorbent, only $20 \%$ of Eu(III) ions are removed by kaolinite, while most of $\mathrm{Eu}(\mathrm{III})$ ions are removed ( $\mathrm{R} \%=93.5 \%$ ) by bentonite. Also, almost complete removals are obtained for $\mathrm{Eu}(\mathrm{III})$ (R\% > 99\%) using $0.04 \mathrm{~g}$ bentonite, while $75 \%$ removal is obtained at the same weight using kaolinite. Increasing the removal efficiency of $\mathrm{Eu}(\mathrm{III})$ by increasing the clay weight can be attributed to the increase in the number of binding sites available for the sorption process. 


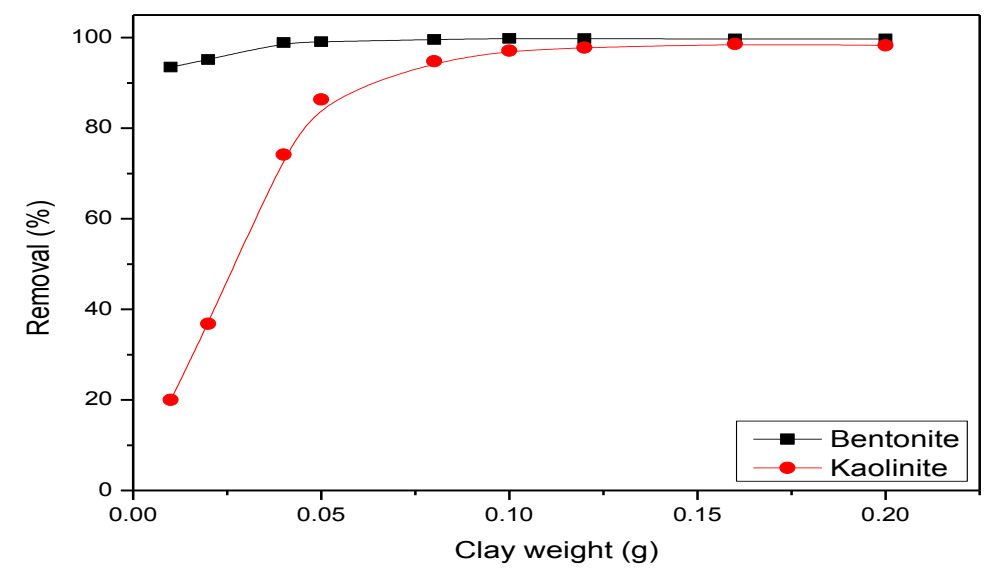

Fig. 3: Effect of adsorbent weight on the removal efficiency of $E u(I I I)\left(C_{M}=10^{-4} M, p H=4, t_{e q}\right.$ 60 min., temperature $298 \pm 1 \mathrm{~K})$.

\section{Effect of Initial Ion Concentrations}

Fig. 4 shows the effect of initial Eu(III) concentration $\left(1 \times 10^{-7} \mathrm{M}-1 \times 10^{-1} \mathrm{M}\right)$ on its sorption efficiency by bentonite and kaolinite. As can be seen from this figure, the applied clays had the ability to remove $\mathrm{Eu}(\mathrm{III})(\mathrm{R} \%>99 \%)$ at very low concentration $\left(1 \times 10^{-7} \mathrm{M}\right)$ as well as at slightly higher concentration $\left(1 \times 10^{-4} \mathrm{M}\right)$. At Eu(III) concentrations higher than $1 \times 10^{-}$ ${ }^{4} \mathrm{M}$, the removal percentage decreased and reached $68 \%$ (for kaolinite) and $64 \%$ for bentonite) at $0.1 \mathrm{M} \mathrm{Eu(III).} \mathrm{The} \mathrm{decrease} \mathrm{in} \mathrm{the} \mathrm{sorption} \mathrm{efficiency} \mathrm{of} \mathrm{Eu(III)} \mathrm{with} \mathrm{increasing}$ its initial concentration may be due to the saturation of the adsorption sites of the clays.

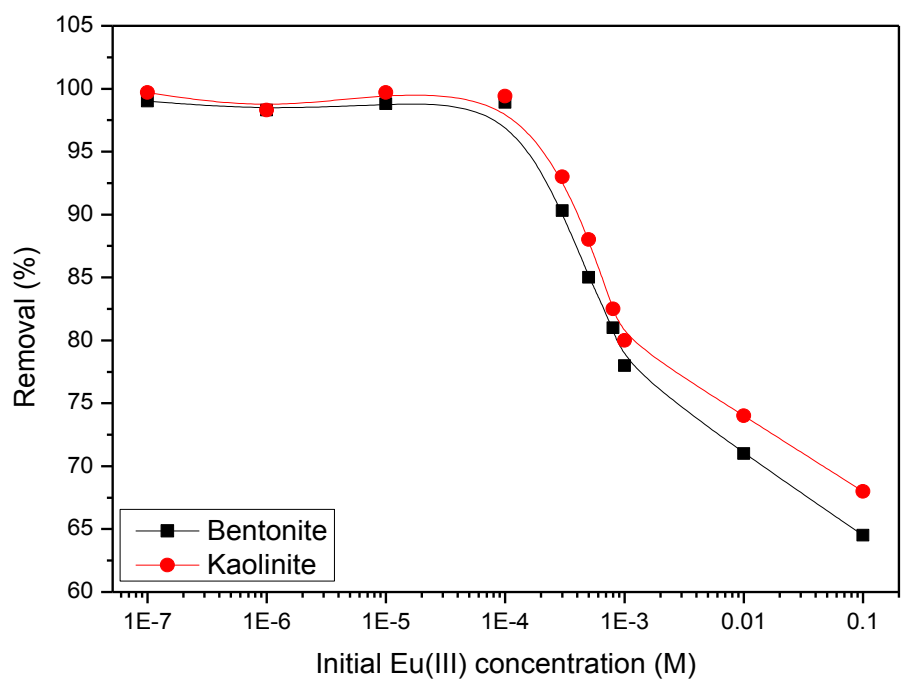

Fig. 4: Effect of initial concentration of Eu(III) on its removal percentage by the employed clays( $\mathrm{pH}=4, \mathrm{t}_{\text {eq }} 60$ min., clay $0.1 \mathrm{~g}$, temperature $\left.298 \pm 1 \mathrm{~K}\right)$. . 


\section{Sorptive flotation studies}

\section{Effect of Collector Concentration}

The effect of the collector concentration on the removal efficiency of Eu(III) by ion flotation and sorptive flotation techniques is shown in Figs. 5A and 5B. From Fig. 5A, it can be noted that flotation of $\mathrm{Eu}(\mathrm{III})$ and $\mathrm{Eu}(\mathrm{III})$-loaded clay using ion and sorptive flotation, respectively, is dependent on SDS concentration. Increasing the SDS concentration enhanced the removal percentage of $\mathrm{Eu}(\mathrm{III})$ and maximum removal of $91 \%$ (for ion flotation and sorptive flotation of Eu-loaded kaolinite) and $96 \%$ (for sorptive flotation of Eu-loaded bentonite) are achieved at $5 \times 10^{-4} \mathrm{M} \mathrm{SDS}$. At $\mathrm{pH} 4$, europium presents in the aqueous as $\mathrm{Eu}^{3+}$ ion as indicated by the precipitation curve of $\mathrm{Eu}(\mathrm{III})$ (Fig. 1). The SDS collector $\left(\mathrm{C}_{12} \mathrm{H}_{15} \mathrm{OSO}_{3} \mathrm{Na}\right)$ ionized in the aqueous solutions to $\mathrm{C}_{12} \mathrm{H}_{15} \mathrm{OSO}_{3}{ }^{-}$and $\mathrm{Na}^{+}$. Thus, the removal percentages attained by ion flotation (Fig. $5 \mathrm{~A}$ ) can be attributed to the electrostatic attraction between the positively charged species of europium, $\mathrm{Eu}^{3+}$, and the negatively charged SDS collector.

The data obtained using CTAB collector (Fig. 5B) show that insignificant removals (R\% $\sim 7 \%$ ) are obtained for $\mathrm{Eu}(\mathrm{III})$ by ion flotation at the studied concentration range of the collector. In the aqueous solution, CTAB collector $\left(\mathrm{C}_{19} \mathrm{H}_{42} \mathrm{NBr}\right)$ ionized to $\mathrm{C}_{19} \mathrm{H}_{42} \mathrm{~N}+$ and $\mathrm{Br}$-. Based on this, the repulsion between the positively charged europium species and CTAB cations is responsible for unfloatability of $\mathrm{Eu}(\mathrm{III})$ by ion flotation. On the contrary, Eu(III)loaded clays are floated with CTAB and the removal efficiency of Eu(III) is increased with increasing the collector concentration and about $94 \%$ of $\mathrm{Eu}(\mathrm{III})$ ions are removed at CTAB concentrations $\geq 5 \times 10^{-4} \mathrm{M}$.

Generally, Bentonite and kaolinite show polar and non-polar surface in homogeneity related to their layer structure. Adsorption of cationic CTAB surfactant occurs through electrostatic interaction between the positively charged head group of the surfactant ion and the negatively charged group of kaolinite and bentonite surface. On the other hand, adsorption of anionic SDS surfactant occurs essentially through dispersive interactions between the nonpolar hydrocarbon chain of the probe molecule and the hydrophobic mineral surface (Hezil et al., 2007).
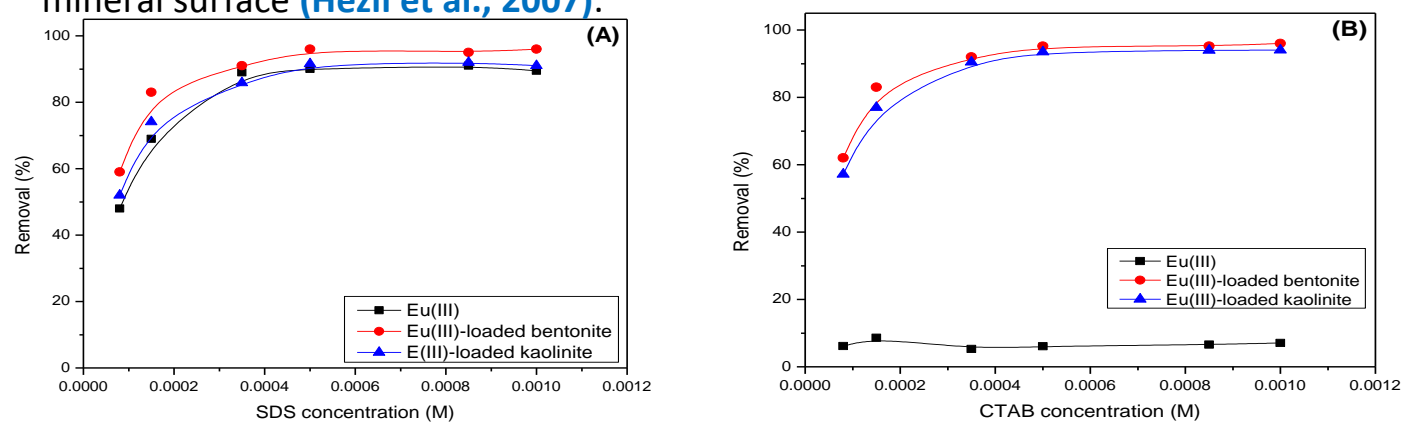

Fig. 5: Effect of collector concentration on the removal efficiency of Eu(III) by ion and sorptive flotation. 


\section{Effect of ethanol concentration}

Fig. 6 illustrates the effect of ethanol concentration $(0.1-2.5 \% \mathrm{v} / \mathrm{v})$ on the flotation of $\mathrm{Eu}$ (III)-loaded clays using SDS and CTAB collectors. The data given in this figure reveal that the removal percentage of $\mathrm{Eu}(\mathrm{III})$ is increased with increasing ethanol concentration and a plateau of maximum removal is achieved at $0.6 \%(\mathrm{v} / \mathrm{v})$ ethanol. At ethanol concentrations higher than $1.6 \%(\mathrm{v} / \mathrm{v})$, floatability of Eu(III)-loaded clays is deleteriously affected. Previous studies reported that the addition of a frother in flotation can simultaneously decrease the surface tension and form a stable foam layer and thus decreasing the respective bubble size via controlling bubble coalescence (Shakir et al., 2010; Cho and Laskowski, 2002; Morgan et al., 1992). Therefore, the number of bubbles available for flotation increases resulting in enhancement in the removal efficiency of Eu(III). The reduction in the flotation efficiency of $\mathrm{Eu}$ (III)-loaded clays at the higher studied ethanol concentrations can be attributed to the competition between ethanol molecules and the collector-colligend product (SDS- or CTAB$\mathrm{Eu}(\mathrm{III})$-loaded clay) for attachment with air bubbles.

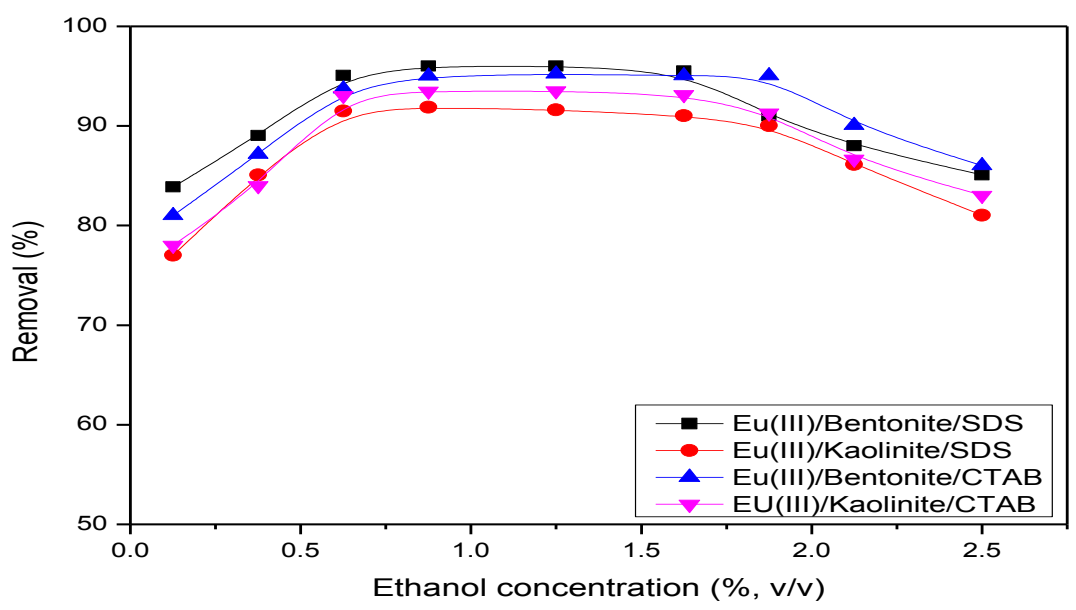

Fig. 6: Effect of ethanol concentration on the flotation efficiency of Eu(III)-loaded clays.

\section{Effect of bubbling time}

The rates of removal of the europium sorbed on clays under consideration were investigated at initial constant concentration of europium $\left(1 \times 10^{-4} \mathrm{M}\right)$, initial constant concentrations of collectors $\left(5 \times 10^{-4} \mathrm{M}\right)$, and one levels of gas flow rate. The results (Fig. 7), indicate that the kinetic curves have similar removal profiles: a relatively rapid initial rate followed by slow approach to a steady state of removal (the maximum removal or ultimate removal). Increase in bubbling time beyond the steady state of removal results in decrease in removal from the maximum due to re-dispersion of some of the dye-collector product back into the bulk solution. 


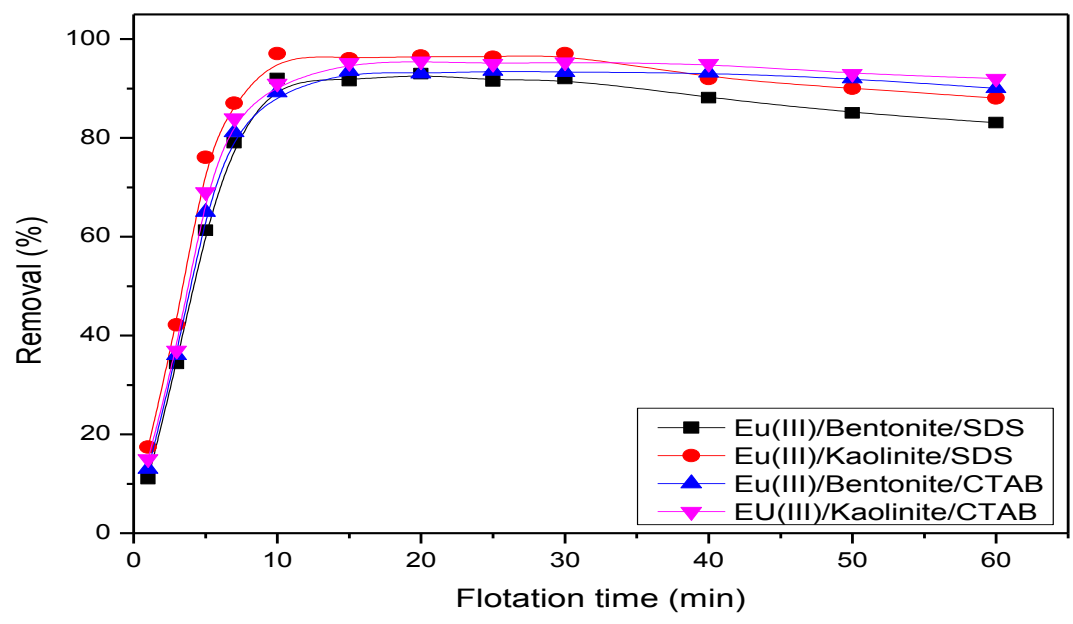

Fig. 7: Flotation of Eu(III)-loaded clays as a function in the flotation time.

\section{Conclusions}

Removal of Eu(III) from aqueous solutions by sorptive flotation process is studied . $\mathrm{Eu}(\mathrm{III})$ is adsorbed onto bentonite and kaolinite clays then Eu(III)-loaded clays is floated using sodium dodecyl sulfate (SDS) and cetyltrimethylammonium bromide (CTAB) collectors . The effect of some variables as solution $\mathrm{pH}$, contact time, initial sorbate concentration, and initial metal concentration on the effectiveness of employed clays for removal of ${ }^{152-154} \mathrm{Eu}$ from aqueous solutions were investigated. Removals > more than $99 \%$ (for bentonite) and $97 \%$ (for kaolinite) are obtained at $\mathrm{pH}=4$. Adsorption of $\mathrm{Eu}(\mathrm{III})$ onto the studied clays is a fast process and most of $\mathrm{Eu}(\mathrm{III})$ ions are removed in the first minute. At the optimum conditions $(\mathrm{pH}=4$, contact time $=60 \mathrm{~min}$, clay weight $=10 \mathrm{~g} / \mathrm{L})$, the floatability of Eu(III)loaded clay was studied at different collector and frother concentrations. Removals of ( 95\%) of Eu(III) are achieved using $5 \times 10^{-4} \mathrm{M}$ SDS or CTAB . Flotation of Eu(III)-loaded clays was found to directly proportional to bubbling time and reached maximum at 15 minutes.

\section{References}

CayllahuaJ.E.B., ToremM.L. , Biosorptive flotation of nickel and aluminum ions from aqueous solution . Desalination 279:195-200 (2011).

Chang Ping Zhang, Ping Gu, Jun Zhao, Dong Zhang, Yue Deng, Research on the treatment of liquid waste containing cesium by an adsorption-microfiltration process with potassium zinc hexacyanoferrate . Journal of Hazardous Materials 167:1057-1062 (2009).

Cho, Y.S.; Laskowski, J.S. Effect of flotation frothers on bubble size and foam stability. Int. J. Miner. Process, 64: $69-80$ (2002). 
Cooper C., Jeang J.Q., Quki S. , Preliminary evaluation of polymeric Fe- and Al-modified clays as adsorbents for heavy metal removal in water treatment. J. Chem. Technol. Biotechnol 77: 546-551(2002).

Hennig C., Reich, T., Daha, R., Scheidegger A.M. , Structure of uranium sorptioncomplexes at montmorillonite edge sites. Radiochim.Acta 90:653-657 (2002).

Hezil N., Guerfi K., Hazourli S., Hammadi A., Zeroual S.,Study of the surface heterogeneity of hydrothermal kaolinite, Geothermal energy (2007).

Katsumata H., Kaneco S., Inomata K., Itoh K., Funasaka K., Masuyama K.,Suzuki T., Ohta K. , Removal of Heavy Metals in Rinsing Wastewater from Plating Factory by Adsorption with Economical Viable Materials.J. Environ.Manage 69:187-191( 2003).

Low K. S., Lee C.K., Leo A.C. Removal of metals from electroplating wastes using banana pith, Bioresour. Technol. 51-227 (1995).

Mathews W., Madsen F.T., Kahr G. Clays . Clay Miner 47:617-629 (1999).

Morgan, J.D., Napper, D.H., Warr, G.G., Nicol, S.K.: Kinetics of recovery of

hexadecyltrimethylammonium bromide by flotation. Langmuir 8, 2124 (1992).

Parks G. A., The isoelectric points of solid oxides, solid hydroxides and aqueous hydroxocomplex systems. Chem. Rev. 65, 177 (1964).

Rubio J. ,Souza M.L., Smith R.W. , Overview of flotation as a wastewater treatment technique Minerals Engineering 15: 139-155 (2002).

SantanderM., ValderramaL. , Guevara M., Rubio , Adsorbing colloidal flotation removing metals ions in a modified jet cell. J. Minerals Engineering 24: 1010-1015 (2011).

Shakir K., Aziz M.,Salama H., Benyamin K. Coflotation of $\mathrm{Cs}^{134}$ fromradioactive process waste water, Radiochim. Acta 41: 47-53 (1987).

Shakir K., Benyamin K., Aziz M. Separation of Co(II) from dilute aqueous solutions by precipitate and adsorbing colloid flotation, J. Radioanal. Nucl. Chem. Articles 172: 329-339 (1993). 
Shakir, K., Elkafrawy, A.F., Ghoneimy, H. F., Beheir, Sh.G., Refaat, M.: Removal of rhodamine B (a basic dye) and thoron (an acidic dye) from dilute aqueous solutions and wastewater simulants by ion flotation. Water Res. 44, 1449 (2010).

Villaescusal., Martinez M., MirallesN., Removal of lead (II) and cadmium (II) from aqueous solutions using grape stalk wasteJ. Chem. Technol. Biotechnol.75 -812 (2000).

ZamboulisD.,Pataroudi S.I., ZouboulisA.I., MatisK.A., The application of sorptive flotation for the removal of metal ions. Desalination 162:159-168 (2004). 


\section{الملخص العربي}

التعويم الامتزازى لعنصر اليوروبيوم الثلاثى المحمل على سطح الطقل من المحاليل المائية

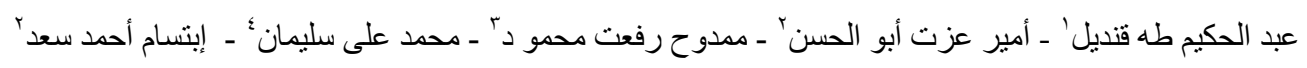

$$
\text { 'قسم الكيمياء ـ كلية العلوم- جامعة حلوان }
$$

كقم الكيمياءـ كلية العلوم- جامعة عين شمس

"قسم الكيمياء النوويةـ المعمل الحار - هيئة الطاقة الذرية

كفاعل مصر البحثى الثانى - هيئة الطاقة الذرية

يهذف هذا البحث إلى إزالة نظير اليوروبيوم المشع من المحاليل المائية باستخدام تقنية التعويم الامتزازى. وذلك بامتزازه

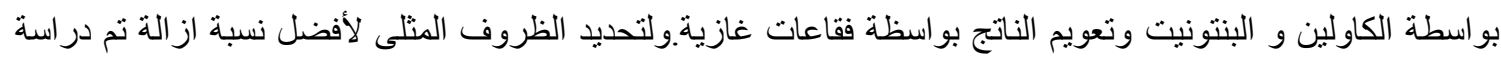
بعض المتغيرات مثل الرقم الهيدروجينى ، زمن التلامس ، وكمية الطفل وكنللك تركيز ايونات عنصر اليوروبيوم .

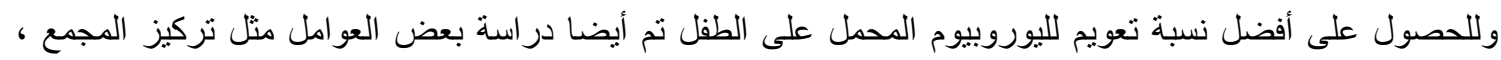

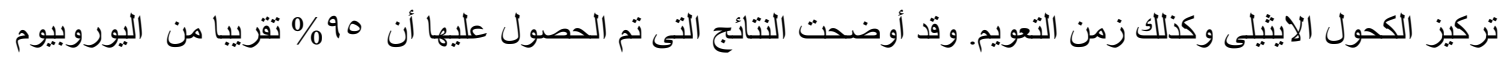
قد تم ازالته بنجاح بالتقنية المستخدمة فى هذه الدراسة. 